\title{
CORRIGENDUM
}

\section{LESS CARE, MORE STRESS: A RHYTHMIC POEM FROM THE ROMAN EMPIRE - CORRIGENDUM}

doi:Io.IoI7/SI75027052100005I, Published by Cambridge University Press, 25 August 202I.

Please note that the Figure I caption was published incorrectly. The correct caption is 'Figure I. The Budapest version (no. 5). Photograph: BHM Aquincum Museum and Archaeological Park / Péter Komjáthy, reproduced with permission'. The author apologises for this error. The author would also like to record that as well as Anna Lefteratou (credited in the article), Shoni Lavie-Driver suggested the possibility of a stressed rhythm. Many thanks to both.

\section{Reference}

Whitmarsh, T. 'Less Care, More Stress: A Rhythmic Poem from the Roman Empire', The Cambridge Classical Journal. Published by Cambridge University Press, 25 August 202I. doi: I0.IOI7/ Si75027052100005I. 